\title{
MICROSTRUCTURAL EVOLUTION DURING THE TRANSIENT LIQUID-PHASE BONDING OF DISSIMILAR NICKEL-BASED SUPERALLOYS OF IN738LC AND NIMONIC 75
}

\author{
RAZVOJ MIKROSTRUKTURE MED SPAJANJEM S PREHODNO \\ TEKOČO FAZO NEENAKIH SUPERZLITIN NA OSNOVI NIKLJA \\ IN738LC IN NIMONIC 75
}

\author{
Meysam Khakian Ghomi, Saeid Nategh, Shamsoddin Mirdamadi \\ Islamic Azad University, Science and Research Branch, Department of Materials Engineering, Tehran, Iran \\ khakian-meysam@yahoo.com, nategh@sharif.ir \\ Prejem rokopisa - received: 2015-04-01; sprejem za objavo - accepted for publication: 2015-05-08
}

doi:10.17222/mit.2015.072

\begin{abstract}
The joining of dissimilar nickel-based superalloys, i.e., IN738LC to Nimonic 75, using transient liquid-phase bonding with a $\mathrm{Ni}-15 \mathrm{Cr}-3.5 \mathrm{~B}$ interlayer (MBF-80) was carried out at temperatures of $1080{ }^{\circ} \mathrm{C}$ to $1180{ }^{\circ} \mathrm{C}$ for different bonding times of $30-150$ min. A joint cross-section was surveyed using optical and scanning electron microscopy. Microstructural examinations showed that after short bonding times, the joint microstructure consists of continuous eutectic intermetallic phases and longer bonding times lead to a eutectic-free microstructure. It was clear that for all the bonding times and temperatures, boride phases were precipitated at the interface of the base metal and the interlayer due to boron diffusion in to the base metals. The results also showed that the morphology of the precipitates in the diffusion-affected zone (DAZ) varies from globular to acicular by increasing the bonding time. Completion of the isothermal solidification, which prevents the formation of continuous intermetallic phases at the joint centerline, was studied at different temperatures.

Keywords: IN738LC, Nimonic 75 superalloy, TLP bonding, isothermal solidification, microstructure

Spajanje različnih superzlitin na osnovi niklja IN738LC na Nimonic 75, z uporabo prehodno tekoče faze z vmesnim slojem $\mathrm{Ni}-15 \mathrm{Cr}-3,5 \mathrm{~B}$ (MBF- 80), je bilo izvedeno pri temperaturah od $1080{ }^{\circ} \mathrm{C}$ do $1180{ }^{\circ} \mathrm{C}$ in pri različnih časih spajanja od $30 \mathrm{~min}$ do 150 min. Prečni prerez spoja je bil pregledan s svetlobno in z vrstično elektronsko mikroskopijo. Mikrostrukturne preiskave so pokazale, da pri kratkih časih spajanja mikrostruktura sestoji iz zvezne evtektične intermetalne faze, dolgi časi spajanja pa povzročijo mikrostrukturo brez evtektika. Izkazalo se je, da se pri vseh časih in temperaturah spajanja, boridna faza zaradi difuzije bora izloča na meji z osnovnim materialom v osnovni material. Rezultati so tudi pokazali, da morfologija izločkov v difuzijsko vplivani coni (DAZ) z naraščanjem časa spajanja varira, od globularne do acikularne. Dokončanje izotermnega strjevanja, ki prepreči nastanek zvezne intermetalne faze na liniji spajanja, je bilo proučevano pri različnih temperaturah.

Ključne besede: IN738LC, superzlitina Nimonic 75, TLP spajanje, izotermno strjevanje, mikrostruktura
\end{abstract}

\section{INTRODUCTION}

IN738LC is one of the most practical casting nickel-based superalloys. IN738LC is strengthened by both solid-solution and precipitation-hardening mechanisms. ${ }^{1}$ Due to the presence of coherent $\gamma^{\prime}$ precipitates in the alloy with a complex chemical composition and a high stability at high temperatures, the alloy can keep its excellent strength in high-temperature operations and severe conditions, such as gas turbine components. Because of the mentioned properties, the alloy is a good choice for utilization in the first rows of gas-turbine hot sections. Also, this alloy has outstanding strength accompanied by excellent creep, fatigue, oxidation and corrosion resistance at high temperatures. ${ }^{2-4}$

Nimonic 75 is an $80 / 20$ nickel-chromium alloy with controlled additions of titanium and carbon. Nimonic 75 first introduced in the 1940s for turbine blades as sealing components and is now mostly used for sheet applications calling for oxidation and scaling resistance coupled with medium strength at high operating temperatures. It is still used in gas-turbine engineering and also for industrial thermal processing, furnace components and heat-treatment equipment. ${ }^{5}$

The weldability of superalloys is very much dependent on the amount of $\mathrm{Al}$ and $\mathrm{Ti}$ in their chemical composition. The high precipitation rate of $\gamma^{\prime}$ in alloys with a large amount of $\mathrm{Al}$ and $\mathrm{Ti}$ make them susceptible to crack propagation during welding. ${ }^{6-8}$ Fusion welding, diffusion bonding and brazing are the three main methods of joining and repairing superalloys that are widely used in power plants and aerospace industries. Solidstate diffusion bonding needs high pressure, time and temperature. Therefore, the process encounters a lot of practical and economic limitations, like growth of grains and precipitates during bonding and lengthy processing causes it to be uneconomic. ${ }^{9}$ Brazing is the other method of joining that uses an interlayer, containing a meltingpoint depressant like $\mathrm{B}, \mathrm{Si}$ and $\mathrm{P}$, as the joining media. The joining temperature must be precisely arranged to melt only the interlayer. Brittle boride, silicide and phosphate continuous phases may be developed in the joint 
Table 1: Chemical composition of base materials and interlayer in mass fractions, $(w / \%)$

Tabela 1: Kemijska sestava osnovnih materialov in vmesne plasti, v masnih odstotkih $(w / \%)$

\begin{tabular}{|c|c|c|c|c|c|c|c|c|c|c|c|c|}
\hline Alloys & $\mathrm{Cr}$ & $\mathrm{Co}$ & $\mathrm{Al}$ & $\mathrm{Ti}$ & $\mathrm{W}$ & $\mathrm{Mo}$ & $\mathrm{Ta}$ & $\mathrm{Nb}$ & $\mathrm{Fe}$ & $\mathrm{C}$ & $\mathrm{B}$ & $\mathrm{Ni}$ \\
\hline IN738LC & 16.23 & 8.56 & 3.41 & 3.45 & 3.05 & 1.73 & 1.57 & 0.67 & 0.08 & 0.09 & 0.0063 & $\mathrm{Bal}$. \\
\hline Nimonic 75 & 20.50 & - & 0.29 & 0.55 & - & - & - & - & 4.78 & 0.10 & - & $\mathrm{Bal}$ \\
\hline MBF-80 & 14.89 & - & - & - & - & - & - & - & - & - & 3.72 & Bal. \\
\hline
\end{tabular}

area during the brazing process and can degrade the joint's properties. ${ }^{10,11}$

Transient liquid-phase (TLP) bonding is a hybrid process of brazing and diffusion bonding. ${ }^{1}$ This method possesses the advantages of brazing and diffusion bonding and makes the joint structure very similar to the base material. In contrast to diffusion bonding, the process does not need any pressure due to the use of a liquid interlayer. ${ }^{12,13}$ The superiority of TLP in comparison with brazing is the completion of isothermal solidification in the bonding temperature. ${ }^{10}$ Also, TLP is widely used in the joining of metals and ceramics. ${ }^{14}$

In the standard models of TLP, there are three individual stages: dissolution, isothermal solidification and solid-state homogenization. Because of the short-range diffusion of melting-point depressant elements in the base metal, the dissolution of the base metal usually needs several minutes. In the isothermal solidification stage, long-term diffusion occurs and therefore the process needs much more time, depending on the bonding temperature and the interlayer type and the time varies from minutes to hours. ${ }^{15}$ By optimizing the time and temperature of the bonding, a joint microstructure that is very similar to the base metal with no discontinuity in the microstructure can be achieved. ${ }^{16}$

In this paper, the effect of bonding time and temperature on the microstructure evolution of the transient liquid-phase bonding of IN 738LC and Nimonic 75 using MBF-80 filler metal was investigated.

\section{MATERIALS AND EXPERIMENTAL PROCEDURES}

IN738LC and Nimonic 75 nickel-based superalloys were used as the base metals in this study. Both superalloys were used in the standard solution heat-treated condition. Commercial Ni-Cr-B in the form of amorphous foil (MBF-80) with a 75- $\mu$ m thickness was used as the interlayer. The chemical compositions of the base materials and the interlayer are given in Table $\mathbf{1}$.

TLP bonding test coupons were cut using EMD wirecut to a size of $10 \mathrm{~mm} \times 10 \mathrm{~mm} \times 5 \mathrm{~mm}$, then they were grounded with a pendulum grinding machine, in order to remove the recast oxide layer from the faying surface of the coupons, and finally cleaned ultrasonically in a acetone bath. The interlayer was cut with a size of $11 \mathrm{~mm} \times 6 \mathrm{~mm}$ and placed between two faying surfaces of the base alloys. In order to prevent the movement of the samples, the assembly was placed in a fixture without any pressure on it. Green stop-off type 1 was used to prevent the flowing out of the molten interlayer. The solidus and liquidus temperatures of the interlayer are $1050{ }^{\circ} \mathrm{C}$ and $1090{ }^{\circ} \mathrm{C}$, respectively. ${ }^{17}$ Therefore, the bonding temperatures were selected above $1050{ }^{\circ} \mathrm{C}$. TLP bonding was performed in a furnace under a vacuum of $10^{-5}$ mbar pressure at different temperatures of (1080, $1120,1150$ and 1180$){ }^{\circ} \mathrm{C}$ and various holding times of $(30,60,120$ and 150) $\mathrm{min}$. In order to investigate the phases formed during the athermal solidification, one test coupon was bonded at $1120{ }^{\circ} \mathrm{C}$ for $5 \mathrm{~min}$. The heattreatment cycle of the bonding is illustrated in Figure 1. The heating rate from $950{ }^{\circ} \mathrm{C}$ to the bonding temperature was set to $20^{\circ} \mathrm{C} / \mathrm{min}$. In order to show the effect of time on the bond strength, a shear test was carried out on all the samples TLP bonded at $1080{ }^{\circ} \mathrm{C}$.

The TLP-bonded test coupons were cut perpendicular to the bonding surface, due to brittleness of the intermetallic phases formed in the bonding centerline, by EDM wirecut and then prepared for metallographic examinations. In order to reveal the microstructure constituent, the samples were etched with Kalling's solution $\left(5 \mathrm{gr} \mathrm{CuCl}_{2}+100 \mathrm{cc} \mathrm{HCl}+100 \mathrm{cc}\right.$ Ethyl alcohol) ${ }^{18}$ Metallographic examinations were carried out using optical and scanning electron microscopy.

\section{RESULTS AND DISCUSSION}

\subsection{Microstructure of the joint}

The microstructure of the TLP-bonded specimen at $1120{ }^{\circ} \mathrm{C}$ and 5 minutes is shown in Figure 2. As can be seen, the bonding area can be divided into six distinct zones:

- Base metal - Nimonic side

- Isothermally Solidified Zone - Nimonic 75 Side (ISZ - Nimonic Side)

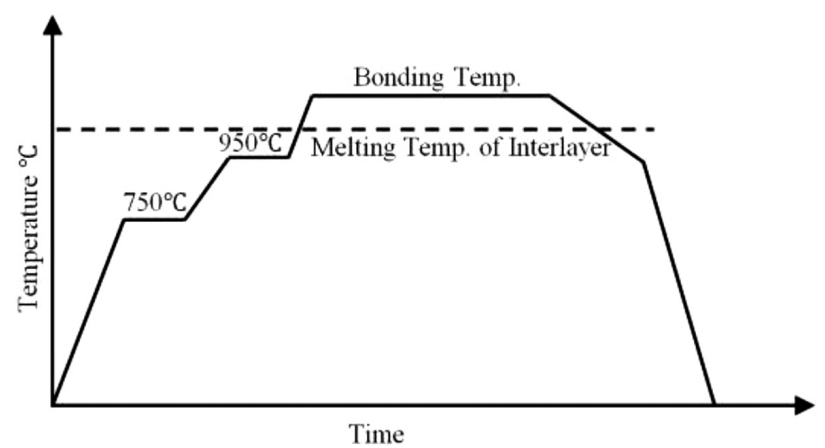

Figure 1: Heat-treatment cycle of the TLP bonding test coupons Slika 1: Potek cikla toplotne obdelave pri TLP spajanju preizkušancev 
Table 2: EDS analysis $(x / \%)$ of phase formed in bond line shown in Figure 2

Tabela 2: EDS analiza $(x / \%)$ faze, ki je nastala na liniji stika, prikazani na Sliki 2

\begin{tabular}{|c|c|c|c|c|c|c|c|c|c|c|}
\hline & $\mathrm{Al}$ & $\mathrm{Ti}$ & $\mathrm{Cr}$ & $\mathrm{Fe}$ & $\mathrm{Co}$ & $\mathrm{Ni}$ & $\mathrm{Nb}$ & $\mathrm{Mo}$ & $\mathrm{Ta}$ & $\mathrm{W}$ \\
\hline ISZ - Inconel Side & 3.12 & 0.94 & 19.41 & 1.23 & 3.01 & 70.43 & 0.64 & 0.52 & 0.28 & 0.41 \\
\hline ISZ - Nimonic Side & 0.57 & 0.46 & 22.12 & 4.26 & 0.35 & 71.21 & 0.34 & 0.40 & 0.0 & 0.28 \\
\hline A (Ni-rich Boride) & 1.08 & 3.83 & 9.18 & 0.71 & 2.28 & 80.70 & 0.85 & 0.56 & 0.80 & 0.0 \\
\hline B $(\gamma$ Eutectic) & 0.97 & 0.53 & 16.27 & 1.64 & 2.47 & 75.84 & 0.60 & 0.66 & 0.30 & 0.71 \\
\hline C $($ Cr-rich Boride) & 0.41 & 0.08 & 89.72 & 0.15 & 0.47 & 5.37 & 0.46 & 2.02 & 0.0 & 1.31 \\
\hline D (Cr-rich Boride) & 0.04 & 0.05 & 87.50 & 0.40 & 0.69 & 5.36 & 1.37 & 1.97 & 1.72 & 0.89 \\
\hline E & 0.75 & 0.36 & 73.05 & 2.34 & 0.0 & 22.04 & 0.63 & 0.44 & 0.13 & 0.25 \\
\hline F & 0.56 & 0.84 & 40.06 & 4.11 & 0.03 & 52.66 & 0.66 & 0.52 & 0.25 & 0.30 \\
\hline
\end{tabular}

- Athermally Solidified Zone (ASZ)

- Isothermally Solidified Zone - Inconel 738 Side (ISZ - Inconel Side)

- Diffusion Affected Zone - Inconel 738 Side (DAZ Inconel Side)

- Base metal - Inconel side

As can be seen in Figure 2a, the ISZ zone on both sides of the ASZ contains a thin layer of $\gamma$ solid solution that formed at the solid/liquid interface during isothermal solidification from the base metal to the joint centerline. The chemical composition of the solid solutions formed on the ISZ - Inconel Side and ISZ - Nimonic Side are shown in Table 2. A significant difference between these two compositions is related to the chemical compositions of the Nimonic 75 and the IN738LC. Also, in Figure 2b, the different phases that are formed during bonding are specified with $\mathrm{A}$ to $\mathrm{F}$.

As the interlayer melts, because the liquid and solid phases are not in the equilibrium condition, base-metal dissolution commences. The diffusion of boron into the base metal and the diffusion of base-metal elements like $\mathrm{Cr}, \mathrm{Fe}, \mathrm{Co}, \mathrm{Al}$ and $\mathrm{Ti}$ into the molten interlayer leads to the equilibrium condition between the liquid and the solid. A chemical analysis of ISZ shows the diffusion of the base-alloy elements that were not present in the primary interlayer. The alloying elements' diffusion from the base metal to the interlayer and also boron diffusion from the interlayer to the base metal increases the liquidus temperature of the interlayer. The dissolution stage continues until the liquidus temperature of the molten interlayer reaches the bonding temperature, and

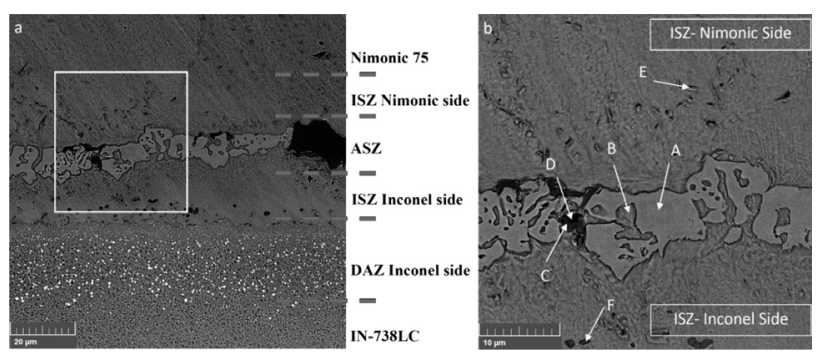

Figure 2: a), b) SEM micrograph of sample bonded at $1120{ }^{\circ} \mathrm{C}$ for $5 \mathrm{~min}$

Slika 2: a), b) SEM-posnetek vzorca, spajanega pri temperaturi $1120{ }^{\circ} \mathrm{C}$, $5 \mathrm{~min}$ then the isothermal solidification starts from the solid/liquid interface to the joint centerline. ${ }^{2,}, 19$

As seen in Table 2, the chemical composition of the ISZ regions adjacent to the base alloys (Inconel Side and Nimonic Side) are not similar; therefore, we can conclude that the time required to reach equilibrium on each side are not equal. In contrast with the TLP bonding of two similar alloys, in which the isothermal solidification starts simultaneously and the eutectic centerline forms symmetrically, in dissimilar alloys the TLP bonding eutectic centerline lies closer to the alloy so that its equilibrium starts earlier.

A variation of the chemical composition that is due to the interdiffusion of elements of the base alloy and the interlayer is the main driving force of solidification for the ISZ. ${ }^{19}$ Since the solid and liquid are in an equilibrium condition during isothermal solidification, the secondary phases cannot form at this stage., ${ }^{3,20}$ The solidification behavior of the remaining liquid during the TLP bonding of pure nickel using the $\mathrm{Ni}-\mathrm{Cr}-\mathrm{B}$ interlayer, before completion of the isothermal solidification, was modeled by $\mathrm{K}$. Ohsasa et al. ${ }^{21}$ The ternary phase diagram of $\mathrm{Ni}-\mathrm{Cr}-\mathrm{B}$, in which the chemical composition of the interlayer is specified, is shown in Figure 3. ${ }^{22}$ During the cooling of the remaining liquid, which is the main

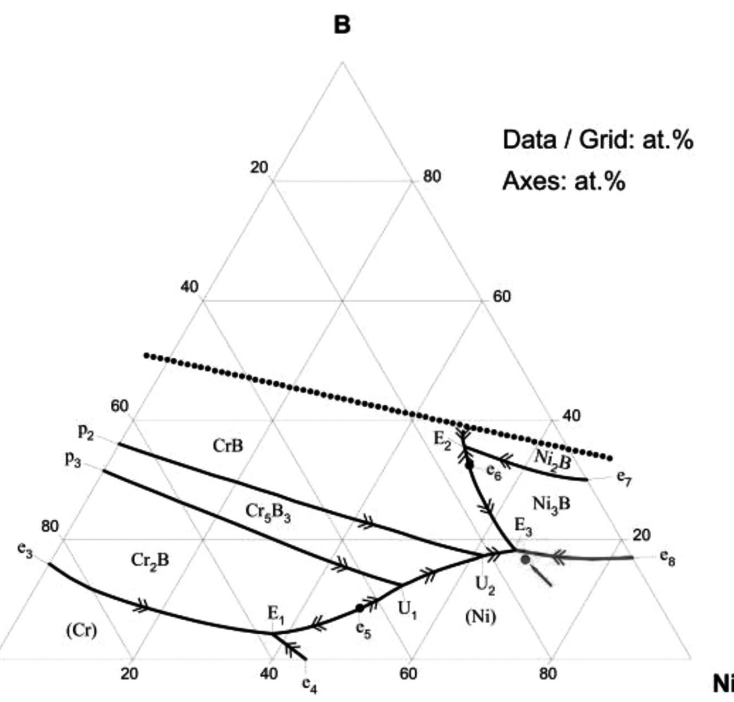

Figure 3: Liquidus projection of ternary phase diagram Ni-Cr-B Slika 3: Projekcija likvidusa v ternarnem faznem diagramu $\mathrm{Ni}-\mathrm{Cr}-\mathrm{B}$ 
driving force for ASZ solidification, $\gamma$ dendrite is the first phase that forms at $1100{ }^{\circ} \mathrm{C}{ }^{21}$ and grows from the solid/liquid interface towards the joint centerline. Solute elements with a partition coefficient less than unity $(\mathrm{k}<$ 1) are rejected into the liquid. Continuous enrichment of the liquid from the solute elements leads to the solute concentration becoming more than the solubility limit of the solute in the $\gamma$ and then the secondary solidification constituents are formed between the dendrites (Phases $\mathrm{E}$ and F). ${ }^{20}$ O. Ojo et al. ${ }^{23}$ and A. Egbewande et al. ${ }^{10}$ observed the formation of these phases in the TLP bonding of IN738 and IN600, by use of a Ni-Cr-B interlayer, respectively.

During the cooling of the liquid and solid-solution growth additional boron is rejected to the liquid, as a result of poor solubility and the low partition coefficient of boron in $\mathrm{Ni}(0.3 \%$ of amount fractions and $\sim 0.008),{ }^{24}$ and then at $1042{ }^{\circ} \mathrm{C}$ the solidification path coincides with the eutectic line that separates the $\gamma$ phase stability region from $\mathrm{Ni}_{3} \mathrm{~B}\left(e_{8}\right.$ line in Figure 3 ) and the $\gamma$ solid solution and nickel boride eutectic phases are formed simultaneously through a binary eutectic transformation $\left(\mathrm{L} \rightarrow \gamma+\mathrm{Ni}_{3} \mathrm{~B}\right)$.

More cooling leads to the growth of the $\gamma$ solid solution and the rejection of boron and the formation of nickel borides lead to a reduction of the Ni concentration and an increment in the $\mathrm{Cr}$ in the remaining liquid $(\mathrm{Cr}$ solubility in $\mathrm{Ni}$ boride is relatively low $(10.11 \%$ of amount fractions). ${ }^{19}$ Also, the $\mathrm{Cr}$ content of the liquid increases by temperature decrement until at $997{ }^{\circ} \mathrm{C}$ the liquid transforms into three phases of $\gamma$ solid solution, nickel boride and chromium boride through a ternary eutectic transformation $\left(\mathrm{L} \rightarrow \gamma+\mathrm{Ni}_{3} \mathrm{~B}+\mathrm{CrB}\right){ }^{21}$ These phases are shown in Figure $\mathbf{2 b}$, and its chemical compositions are shown in Table 2.

\subsection{Effect of time and temperature on the microstruc- ture of the TLP bonds}

In order to investigate the effect of time on the microstructure of the TLP bonds, bonding was performed at $1080{ }^{\circ} \mathrm{C}$ for $30,60,120$ and $150 \mathrm{~min}$. It was clear that the thickness of the intermetallic phases decreases with the increasing time (Figure 4). The extent of isothermal solidification during TLP bonding depends on the amount and rate of boron diffusion into the base alloys. The thickness of remaining interlayer, which can transform into a continuous eutectic centerline during cooling, decreases for longer bonding times. It was clear that with an increasing time from 30 to $60 \mathrm{~min}$, the thickness of the centerline eutectic decreases. After $120 \mathrm{~min}$ there is no continuous eutectic and after a longer time (150 min) there is a negligible amount of intermetallic phases. The results showed that $150 \mathrm{~min}$ is not enough for the completion of isothermal solidification at $1080{ }^{\circ} \mathrm{C}$. Figure 5 shows the ASZ thickness and the shear strength of the bond at different times. It is clear that a dominant

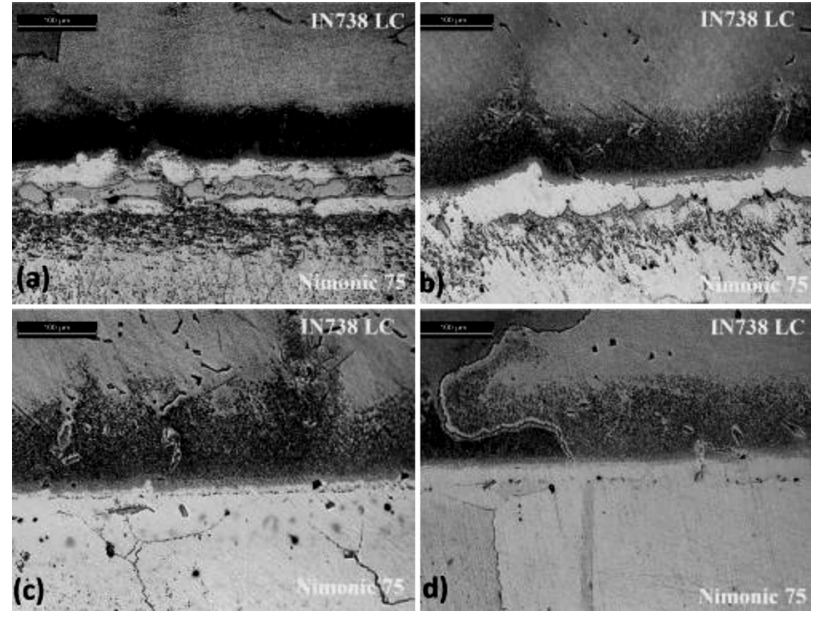

Figure 4: Light micrograph of TLP-bonded specimen at $1080{ }^{\circ} \mathrm{C}$ : a) $30 \mathrm{~min}$, b) $60 \mathrm{~min}$, c) $120 \mathrm{~min}$, d) $150 \mathrm{~min}$

Slika 4: Svetlobni posnetek vzorcev, spajanih s TLP, na temperaturi $1080{ }^{\circ} \mathrm{C}$ : a) $30 \mathrm{~min}$, b) $60 \mathrm{~min}$, c) $120 \mathrm{~min}$, d) $150 \mathrm{~min}$

increment in strength can be associated with a decrement of the ASZ thickness. The shear strengths of Nimonic 75 and IN738 at room temperature are $650 \mathrm{MPa}$ and 860 $\mathrm{MPa}$, respectively. The results showed that the strength of the TLP-bonded specimen at $1080{ }^{\circ} \mathrm{C}$ is less than the strength of the base metals.

Figure 6 shows the optical microstructure of TLP bonding at $1120{ }^{\circ} \mathrm{C}, 1150{ }^{\circ} \mathrm{C}$ after $120 \mathrm{~min}$ and $1180{ }^{\circ} \mathrm{C}$ after $150 \mathrm{~min}$. It was clear that at bonding temperatures of $1120{ }^{\circ} \mathrm{C}$ and $1150{ }^{\circ} \mathrm{C}$ there was no centerline eutectic micro-constituents, and isothermal solidification was complete. It can be seen that with increasing bonding temperatures from $1120{ }^{\circ} \mathrm{C}$ to $1150{ }^{\circ} \mathrm{C}$, significant microstructural changes occurred in the DAZ of IN738, but no changes happened in the bond line. It is expected that increasing the bonding temperature and consequently increasing the diffusion rate of boron, decreases the time required for completing the isothermal solidification. But as shown in Figure 6c, at $1180{ }^{\circ} \mathrm{C}$

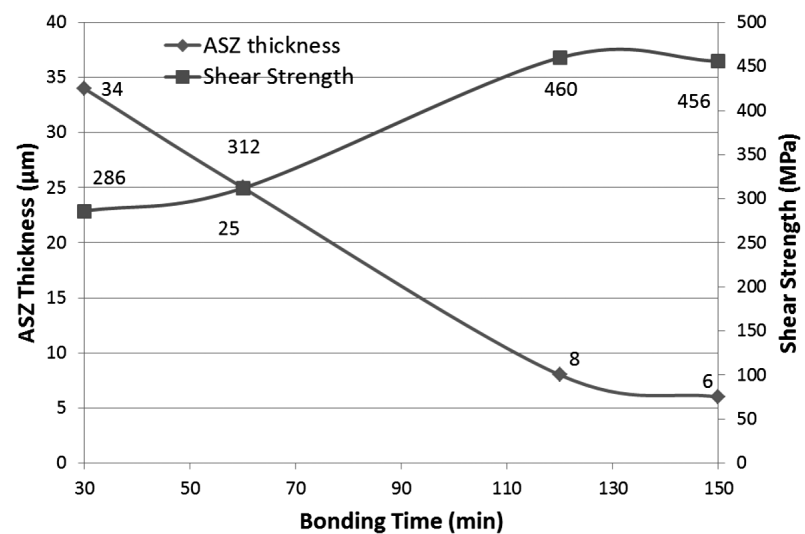

Figure 5: Shear strength and ASZ thickness versus bonding time at $1080{ }^{\circ} \mathrm{C}$

Slika 5: Odvisnost strižne trdnosti in debeline ASZ od časa spajanja na temperaturi $1080{ }^{\circ} \mathrm{C}$ 

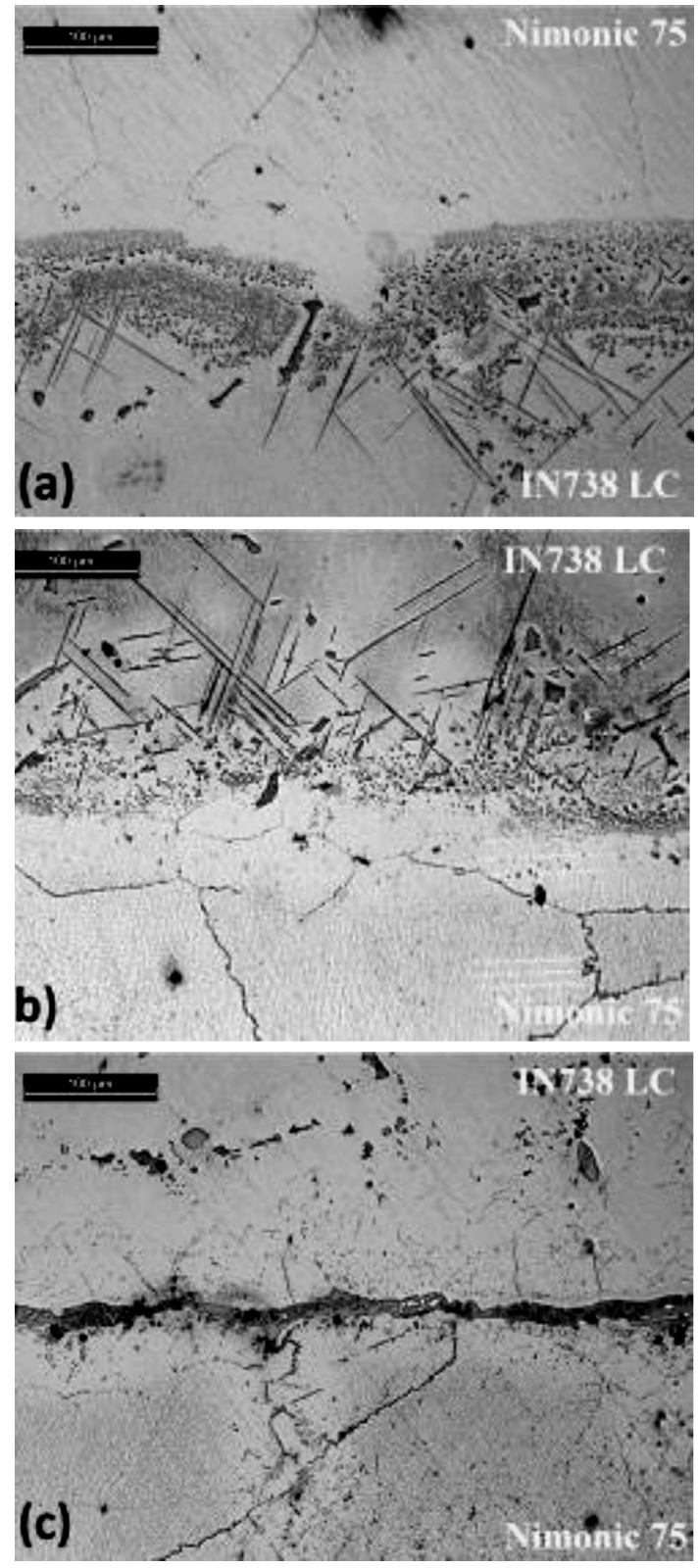

Figure 6: Light micrograph of TLP-bonded specimens at: a) $1120{ }^{\circ} \mathrm{C}$ for $120 \mathrm{~min}$, b) $1150{ }^{\circ} \mathrm{C}$ for $120 \mathrm{~min}$, c) $1180{ }^{\circ} \mathrm{C}$ for $150 \mathrm{~min}$

Slika 6: Svetlobni posnetek vzorcev, spajanih s TLP: a) $1120{ }^{\circ} \mathrm{C}-$ $\left.120 \mathrm{~min}, \mathrm{~b}) 1150{ }^{\circ} \mathrm{C}-120 \mathrm{~min}, \mathrm{c}\right) 1180^{\circ} \mathrm{C}-150 \mathrm{~min}$

there are significant amounts of centerline eutectic in the bonding after $150 \mathrm{~min}$ and isothermal solidification was not completed yet. O. Idouw et al. ${ }^{25}$ reported that in TLP bonding of IN738, increasing the bonding temperature from $1170{ }^{\circ} \mathrm{C}$ leads to the diffusion of aluminum and titanium into the molten interlayer and a reduction of the isothermal solidification rate may happen. They reported that the diffusion of titanium to the molten layer leads to the formation of a Ni-Ti rich phase, M2SC-type sulphocarbide, chromium-rich boride and a $\gamma-\gamma$ ' centerline eutectic. These phases are very stable and hard to solute. Therefore, they can decrease the rate of isothermal solidification and the completion of the process will be postponed.

\subsection{Precipitation in the diffusion-affected zone (DAZ)}

Boride precipitation is expected in the base metal where the concentration of boron is more than its solubility limit in a $\gamma$ solid solution. ${ }^{23}$ The solubility limit of boron in nickel is $0.3 \%$ of amount fractions over the range of $1065-1110{ }^{\circ} \mathrm{C}$, according to the $\mathrm{Ni}-\mathrm{B}$ binary phase diagram. ${ }^{26}$ Therefore, the diffusion of boron into the base metal during the holding at bonding temperature leads to the formation of boride precipitates in the DAZ. These precipitates are shown in Figures $\mathbf{7}$ and $\mathbf{8}$ in two morphologies: globular and acicular.

When the distance between the precipitates and the interface increases the morphology of the precipitates changes from globular to acicular. As mention before, dissolution is the first stage of TLP bonding where the base-alloys solute elements diffuse into the base alloy until the equilibrium condition between solid/liquid is achieved. Therefore, the alloying-elements concentration in the base metal layer adjacent to the bond is poorer than the other layers. As shown in Table 3, the amount

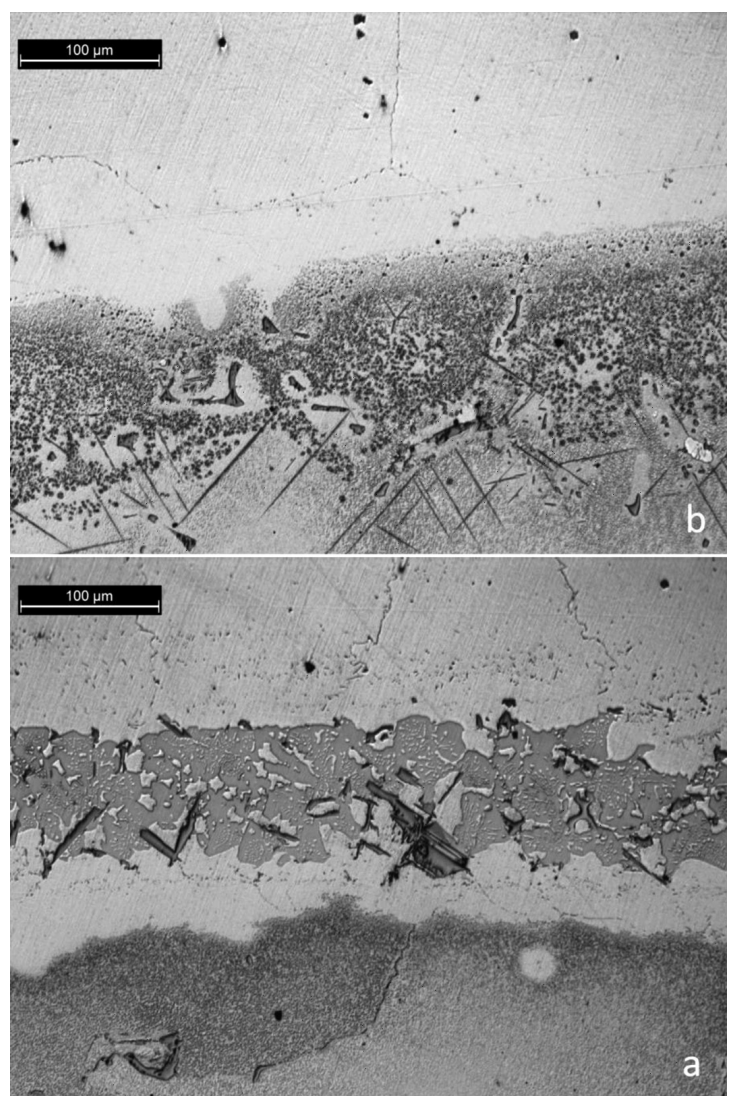

Figure 7: Variation of precipitates's morphology in DAZ at $1120{ }^{\circ} \mathrm{C}$ with time from a) $5 \mathrm{~min}$ to b) $120 \mathrm{~min}$. The morphology changes from globular to globular/acicular.

Slika 7: Spreminjanje morfologije izločkov v DAZ na temperaturi $1120{ }^{\circ} \mathrm{C}$, v odvisnosti od časa od a) $5 \mathrm{~min}$ do b) $120 \mathrm{~min}$. Morfologija se spreminja od globularne do globularno/acikularne. 

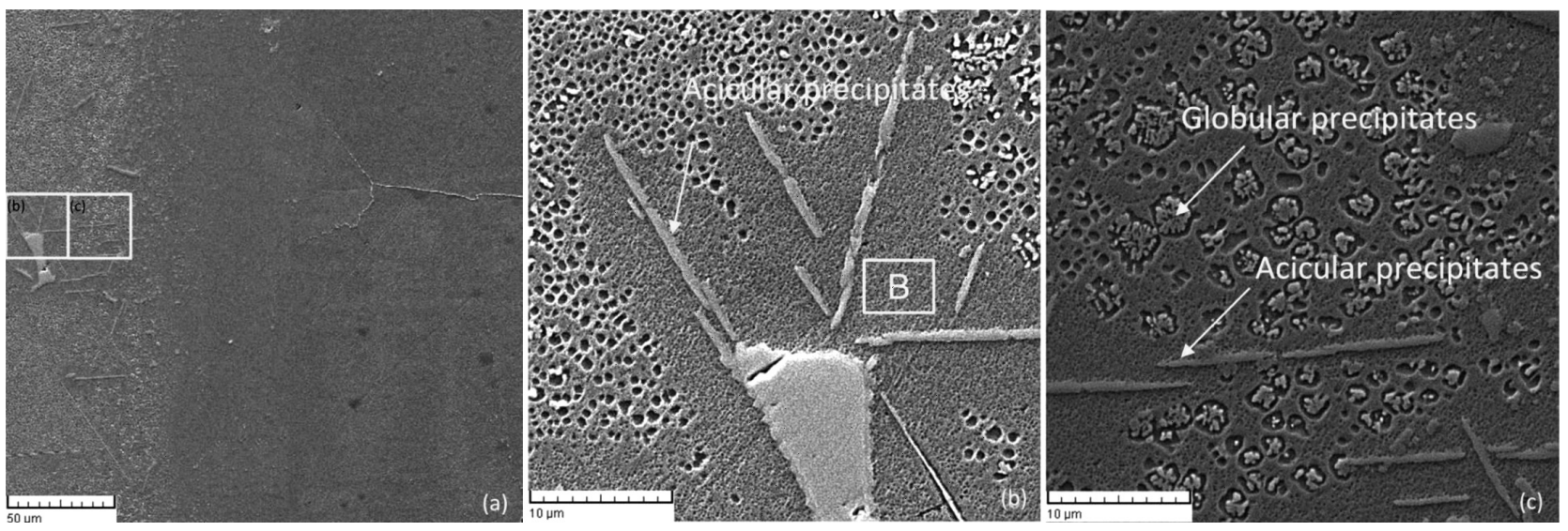

Figure 8: a) SEM micrograph of specimen TLP-bonded at $1150{ }^{\circ} \mathrm{C}$ for $150 \mathrm{~min}, \mathrm{~b}$ ) and c) specified area in a) showed by b) and c) respectively Slika 8: SEM-posnetek vzorcev, spajanih s TLP, na temperaturi $1150 \mathrm{C}, 150 \mathrm{~min}, \mathrm{~b}$ ) in c) določeno področje a) prikazano na b) oz. c)

Table 3: EDS analysis of phases shown in Figure $8(x / \%)$

Tabela 3: EDS analiza faz prikazanih na Sliki $8(x / \%)$

\begin{tabular}{|c|c|c|c|c|c|c|c|c|c|}
\hline & $\mathrm{Al}$ & $\mathrm{Ti}$ & $\mathrm{Cr}$ & $\mathrm{Co}$ & $\mathrm{Ni}$ & $\mathrm{Nb}$ & Mo & $\mathrm{Ta}$ & $\mathrm{W}$ \\
\hline Acicular Precipitates & 2.25 & 39.45 & 7.99 & 2.81 & 18.78 & 7.49 & 5.07 & 11.46 & 4.69 \\
\hline Globular Precipitates & 8.44 & 3.53 & 38.70 & 4.06 & 34.68 & 0.57 & 5.28 & 0.61 & 4.12 \\
\hline B & 3.71 & 0.46 & 25.65 & 6.32 & 60.61 & 0 & 0.60 & 1.15 & 1.49 \\
\hline
\end{tabular}

of alloying elements in the precipitates closer to the bonding interface (globular precipitates) is less than the ones further than the bond line (acicular precipitates). As seen in Table 3, the high chromium content of the globular precipitates leads to a significant depletion of the chromium around them. Since the $\mathrm{Cr}$ is the main element for resistance to corrosion of the base alloy, the depletion of $\mathrm{Cr}$ around these precipitates leads to a reduction of the matrix's corrosion resistance. ${ }^{27}$ Moreover, a high concentration of $\gamma^{\prime}$-formers in the precipitates leads to the depletion of $\mathrm{Al}$ and $\mathrm{Ti}$ in the matrix around the precipitates, and as seen in Figure 8, there is no $\gamma$, particle around them.

The morphology of the precipitates varies by increasing the bonding temperature from the globular to the acicular morphology, and at $1150{ }^{\circ} \mathrm{C}$ the acicular morphology is dominant (Figures 6a and 6b). The reason is probably related to more diffusion of the alloying elements at the higher temperature and greater homogeneity of the chemical composition in the DAZ. The other point that can be gained from Figure $\mathbf{6 c}$ is that the amount of precipitates in the DAZ decreases by raising the temperature, such that at $1180{ }^{\circ} \mathrm{C}$ there is no acicular and globular precipitate. It can be concluded that these precipitates may be dissolved at temperatures lower than $1180{ }^{\circ} \mathrm{C}$.

Figure 7 shows that at $1120{ }^{\circ} \mathrm{C}$, the morphology of the precipitates varies from globular to globular/acicular by increasing the holding time from 5 to $120 \mathrm{~min}$. This phenomenon is related to more diffusion of boron into the base alloy at longer times and implies that the formation of acicular precipitates need more alloying elements than globular precipitates (Table 3).
Figure 8 shows the bond interface in a specimen TLP bonded at $1120{ }^{\circ} \mathrm{C}$ for $150 \mathrm{~min}$. Boron was detected in all precipitates, but their accurate concentration could not be reported quantitatively due to X-ray absorption of the EDS analyzer window. The compositional analyses shown in Table 3 suggests that globular precipitates are borides rich in $\mathrm{Ni}, \mathrm{Cr}, \mathrm{Mo}, \mathrm{W}$ and $\mathrm{Al}$ and acicular precipitates are borides rich in $\mathrm{Ti}, \mathrm{Ta}, \mathrm{Mo}, \mathrm{Nb}$ and $\mathrm{W}$. O. Ojo et $\mathrm{al}^{22}$ and O. Idowu et al. ${ }^{24}$ observed boride precipitates rich in Cr, $\mathrm{W}$ and Mo in TLP bonding of IN738 by a Ni-Cr-B interlayer at $1130{ }^{\circ} \mathrm{C}$. Also, it can be seen that there are lots of very fine $\gamma^{\prime}$ around acicular precipitates. The reason is related to the absorption of $\mathrm{Ti}$ by these precipitates so that the concentration of the $\gamma$ ' former element is less than normal. Since the Nimonic 75 does not have any boride formers in its chemical composition, no precipitate was observed in its diffusion-affected zone. Figures $\mathbf{8 b}$ and $\mathbf{8 c}$ show the different zones specified in Figure 8a.

\section{CONCLUSION}

The effect of time and temperature on the TLP bonding of the dissimilar nickel-based super alloys IN738LC and Nimonic 75 using an MBF-80 interlayer was investigated. The following conclusions can be drawn from this study:

- Before completion of the isothermal solidification, the microstructure of the joint centerline consists of three eutectic phases: $\gamma$ solid solution, Ni-rich boride and $\mathrm{Cr}$-rich boride.

- DAZ precipitates are formed due to boron diffusion from the interlayer to the base metal during a 
solid-state transformation. Boride precipitates were observed in the DAZ at bonding temperatures up to $1150{ }^{\circ} \mathrm{C}$. However, at a bonding temperature of 1180 ${ }^{\circ} \mathrm{C}$, the boride precipitates were not observed.

- At a given bonding temperature, the morphology of the DAZ precipitates changes from globular to globular-acicular with an increasing bonding time.

- Boride precipitation in Nimonic 75 DAZ did not occur due to a lack of boride-forming elements in its chemical composition.

- A reduction in the isothermal solidification rate was observed when TLP bonding at $1180{ }^{\circ} \mathrm{C}$.

\section{REFERENCES}

${ }^{1}$ M. Mosallaee, A. Ekrami, K. Ohsasa, K. Matsuura, Microstructural evolution in the transient-liquid-phase bonding area of IN-738LC/ BNi-3/IN-738LC, Metallurgical and Materials Transactions A, 39 (2008) 10, 2389-2402, doi:10.1007/s11661-008-9588-0

${ }^{2}$ M. Abdelfatah, O. Ojo, On the extension of processing time with increase in temperature during transient-liquid phase bonding, Metallurgical and Materials Transactions A, 40 (2009) 2, 377-385, doi:10.1007/s11661-008-9726-8

${ }^{3}$ M. Pouranvari, A. Ekrami, A. Kokabi, Aging response of transient liquid phase bonded wrought IN718 superalloy: influence of post-bond heat treatment, Science and Technology of Welding and Joining, 19 (2014) 2, 105-110, doi:10.1179/1362171813Y. 0000000170

${ }^{4}$ M. Pouranvari, A. Ekrami, A. Kokabi, Diffusion Brazing Metallurgy of IN718/Ni-Cr-Si-B-Fe/IN718, Welding journal, 93 (2014) 2, 60s-68s, doi:10.1179/1743284713Y.0000000320

${ }^{5} \mathrm{O}$. Kalvenes, Studies of the reaction of Nimonic 75 with Co2, Corrosion Science, 4 (1964), 211-220, doi:10.1016/0010-938X(64) 90020-4

${ }^{6}$ O. Ojo, N. Richards, M. Charturvedi, Effect of gap size and process parameters on diffusion brazing of Inconel 738, Science and Technology of Welding \& Joining, 9 (2004) 3, 209-220, doi:10.1179/ 136217104225012175

${ }^{7}$ M. Pouranvari, A. Ekrami, A. H. Kokabi, Effect of the bonding time on the microstructure and mechanical properties of a transient liquid phase bonded 718 using a Ni-Cr-B filler alloy, Mater. Tehnol., 47 (2013) 593-599

${ }^{8}$ N. Wikstrom, A. Egbewande, O. Ojo, High temperature diffusion induced liquid phase joining of a heat resistant alloy, Journal of Alloys and Compounds, 460 (2008) 1, 379-385, doi:10.1016/ j.jallcom.2007.06.066

${ }^{9} \mathrm{X}$. Wu, R. Chandel, H. Li, Evaluation of transient liquid phase bonding between nickel-based superalloys, Journal of Materials Science, 36 (2001) 6, 1539-1546, doi:10.1023/A:1017513200502

${ }^{10}$ A. Egbewande, C. Chukwukaeme, O. Ojo, Joining of superalloy Inconel 600 by diffusion induced isothermal solidification of a liquated insert metal, Materials Characterization, 59 (2008) 8 , 1051-1058, doi:10.1016/j.matchar.2007.08.023

${ }^{11}$ R. Saha, T. Khan, Microstructural developments in TLP bonds using thin interlayers based on Ni-B coatings, Materials Characterization, 60 (2009) 9, 1001-1007, doi:10.1016/j.matchar.2009.04.002
${ }^{12}$ W. Gale, D. Butts, Transient liquid phase bonding, Science and Technology of Welding \& Joining, 9 (2004) 4, 283-300, doi:10.1179/136217104225021724

${ }^{13}$ F. Jalilian, M. Jahazi, R. Drew, Microstructural evolution during transient liquid phase bonding of Inconel 617 using Ni-Si-B filler metal, Materials Science and Engineering: A, 423 (2006) 1, 269-281, doi:10.1016/j.msea.2006.02.030

${ }^{14}$ M. Pouranvari, A. Ekrami, A. Kokabi, TLP bonding of cast IN718 nickel based superalloy: Process-microstructure-strength characteristics, Materials Science and Engineering: A, 568 (2013), 76-82, doi:10.1016/j.msea.2013.01.029

${ }^{15}$ Dffusion Brazing, in ASM Handbook, ASM Internation, 2005, 207-221

${ }^{16}$ M. Pouranvari, A. Ekrami, A. Kokabi, Solidification and solid state phenomena during TLP bonding of IN718 superalloy using Ni-Si-B ternary filler alloy, Journal of Alloys and Compounds, 563 (2013), 143-149, doi:10.1016/j.jallcom.2013.02.100

${ }^{17}$ A. Rabinkin, Brazing with (NiCoCr)-B-Si amorphous brazing filler metals: alloys, processing, joint structure, properties, applications, Science and Technology of Welding \& Joining, 9 (2004) 3, 181-199, doi:10.1179/136217104225012300

${ }^{18}$ T. A. Christman, K. B. Small, Guide to etching specialty alloys, Advanced materials \& processes, (2008) 10192/1881463/ amp16602p032.pdf/4d43b19b-45b7-4893-84a7-d6babb9505e5

${ }^{19}$ M. Pouranvari, A. Ekrami, A. Kokabi, Phase transformations during diffusion brazing of IN718/Ni-Cr-B/IN718, Materials Science and Technology, 29 (2013) 8, 980-984, doi:10.1179/1743284713Y. 0000000238

${ }^{20} \mathrm{~N}$. Wikstrom, O. Ojo, M. Chaturvedi, Influence of process parameters on microstructure of transient liquid phase bonded Inconel 738LC superalloy with Amdry DF-3 interlayer, Materials Science and Engineering: A, 417 (2006) 1, 299-306, doi:10.1016/ j.msea.2005.10.056

${ }^{21}$ K. Ohsasa, T. Narita, T. Shinmura, Numerical modeling of the transient liquid phase bonding process of Ni using Ni-B-Cr ternary filler metal, Journal of Phase Equilibria, 20 (1999) 3, 199-206, doi:10.1361/105497199770335721

${ }^{22}$ A. Bondar, B-Cr-Ni Boron-Chromium-Nickel, Landolt-Börnstein, Numerical Data and Functional Relationships in Science and Technology (New Series). Group IV, Physical Chemistry, 2006 153-167, doi:10.1007/978-3-540-47004-5_19

${ }^{23}$ O. Ojo, N. Richards, M. Chaturvedi, Isothermal solidification during transient liquid phase bonding of Inconel 738 superalloy, Science and Technology of Welding \& Joining, 9 (2004) 6, 532-540, doi:10.1179/174329304X8702

${ }^{24}$ Alloy Phase Diagrams, 10 ed, ASM Handbook, 3, ASM International, 1992

${ }^{25}$ O. Idowu, N. Richards, M. Chaturvedi, Effect of bonding temperature on isothermal solidification rate during transient liquid phase bonding of Inconel 738LC superalloy, Materials Science and Engineering: A, 397 (2005) 1, 98-112, doi:10.1016/j.msea.2005. 01.055

${ }^{26}$ K. Tokoro, N. Wikstrom, O. Ojo, M. Chaturvedi, Variation in diffusion-induced solidification rate of liquated $\mathrm{Ni}-\mathrm{Cr}-\mathrm{B}$ insert during TLP bonding of Waspaloy superalloy, Materials Science and Engineering: A, 477 (2008) 1, 311-318, doi:10.1016/j.msea. 2007.05.069

${ }^{27} \mathrm{M}$. Pouranvari, Isothermal solidification during transient liquid-phase bonding of GTD-111/Ni-Si-B/GTD-111, Mater. Tehnol., 48 (2014) $1,113-118$ 